\title{
The Importance of the Philosophy, Attitude, Perception, and Knowledge of Extension Workers in Transferring Sustainable Agricultural Practices to Malaysian Farmers
}

\author{
Neda Tiraieyari ${ }^{1}$, Azimi Hamzah ${ }^{1}$, Bahaman Abu Samah ${ }^{1} \&$ Jejak Uli ${ }^{2}$ \\ ${ }^{1}$ Institute for Social Science Studies, University Putra Malaysia, Malaysia \\ ${ }^{2}$ Faculty of Defence Studies and Management, National Defense University of Malaysia, Malaysia \\ Correspondence: Neda Tiraieyari, Institute for Social Science Studies, University Putra Malaysia, Malaysia. Tel: \\ 6-3-8946-1866. E-mail: ntiraie@yahoo.com
}

Received: June 20, 2013 Accepted: September 3, 2013 Online Published: October 29, 2013

doi:10.5539/ass.v9n15p289 URL: http://dx.doi.org/10.5539/ass.v9n15p289

\begin{abstract}
Sustainable agriculture is relatively new in Malaysia. The Department of Agriculture (DOA) has earmarked agricultural extension workers in the transfer of sustainable agricultural practices (SAP) to farmers. The purpose of this study is to investigate the importance of the attitude, perception, philosophy, and knowledge of extension workers in transferring SAP to Malaysian farmers. A questionnaire was used to collect data from a random sample of 400 extension workers associated with the DOA in west Malaysia. Quantitative data were analyzed using Pearson correlation and multiple linear regressions (MLR). Findings supported a positive relationship between extension workers' philosophy, attitude, perception, and knowledge in transferring SAP to farmers. MLR results showed that variables selected for this study explained $62.3 \%$ of the variance in transferring SAP. Results support the importance of variables among the extension workers who transfer sustainable practices to farmers.
\end{abstract}

Keywords: attitude, perception, philosophy, knowledge, sustainable agriculture, extension workers, Malaysia

\section{Introduction}

The majority of farmers in developing countries practicing intensive farming have caused environmental damage (Barrow, Lawrence \& Walker., 2009). Largely, the solution to this issue lies in sustainable agriculture. Sustainable agriculture systems are based on small and profitable farms that use less off-farm inputs, sustain high biotic diversity, apply appropriate technologies, and switch to renewable forms of energy (Horrigan, Lawrence \& Walker., 2002). According to Williams (2000), sustainable agriculture has three components; that is, being economically sound, environmentally protective, and socially acceptable. Scholars define sustainable agriculture as a knowledge intensive system to produce foods and fibres (Pretty, 1995; Chizari, Lindner \& Lashkarara, 1999; Cho \& Boland, 2004).

Recently, attention has been given to SAP in Malaysia. Programs such as integrated farming systems (IFS), organic farming (OF) and good agricultural practices (GAP) are being advertised by agricultural agencies such as the DOA to eliminate unsustainable agriculture in Malaysia (Tiraieyari \& Uli, 2011). For this purpose, the current mission of the DOA is to provide information on SAP through extension services to Malaysian farmers. In developing countries such as Malaysia, extension is identified as the delivery of a base system of knowledge and technology (Röling \& Van de Fliert, 1994). The SAP is typically transferred to the farmers by extension workers. Therefore, extension workers are considered as source of information and they play a crucial role in the success of SAP. They can influence farmers to adopt the program. However, prior to influencing farmers to adopt a program, extension workers must be convinced themselves about the importance and necessity of the program. Extension workers' attitudes regarding the concepts of SAP are essential in building strong, sustainable agriculture in the country. Attitudes, perception, value, and beliefs are important determinates of human behaviour. Liaghati, Veisi, Hematyar, and Ahmadzadeh (2008) reported that attitude is one of the key main determinants of human behaviour and one which provides direction to individual performance. 
Udoto and Flowers (2001) stated that extension workers 'positive attitude on SAP might persuade extension workers to transfer SAP to farmers'. They further contend that understanding extension workers' philosophy of SAP is also important because if extension workers acquire positive values and beliefs about SAP, they are more likely to educate farmers about SAP to persuade farmers to adopt such practices. Similarly, Agunga (1995) stated that extension workers first should be convinced of the value of sustainable agriculture in order to adequately transfer the practices to farmers. Another study (Williams \& Wise, 1997) indicated that the positive attitudes of extension workers towards SAP would influence them to transfer SAP to farmers. On the contrary, results of the study conducted by Muma, Martin, Shelley, and Holmes (2010) showed that although educators agree with concepts and practices regarding SAP, this agreement did not influence the extent to which they teach topics in SAP. They further contend that results did not appear to have a relationship between being in agreement with SAP concepts and the extent to which they teach the subject.

Extension workers' knowledge of the subject matter is another factor that influences how they transfer SAP. Their knowledge about the concept of sustainability is essential to move the program forward (Minarovic and Mueller, 2000). According to Al-Subaiee, Yoder, and Thompson (2005), the first step in shifting unsustainable agriculture to a sustainable agriculture is to educate extension workers in order to build a good understanding of the concept and its practices. Results of the study conducted by Agunga (1995) showed that extension workers in the United States were not interested in promoting SAP to farmers due to a lack of fully understanding the program. Results of a project conducted by Worstell (1995) in the United States showed that extension workers needed more training and information on SAP. Alonge and Martin (1995) stated that the first step toward farmers' adoption a new program or practices is to provide sufficient information for them through extension workers. Therefore, extension workers must be knowledgeable about the program they are transferring to farmers. Karbasioun, Biemans, and Mulder (2007) and Chizari, Lindner, and Lashkarara (2001) reported that one of the major obstacles for the adoption of SAP in Iran is that extension workers have limited knowledge of SAP.

Past research conducted to determine extension workers' attitude, knowledge, and perception toward SAP (Tiraieyari, Hamzah, Samah \& Uli., 2013a; Tiraieyari, Hamzah, Samah \& Uli., 2013b; Chizari, Lindner \& Zohgie .,1999; Minarovic and Mueller, 2000; Straquadine, 1997; Allahyari, Branch \& Rasht., 2008; Allahyari, 2009; Udoto and Flowers, 2001; Williams and Wise, 1997). Researchers contend that generating an acceptable level of knowledge and acceptable attitudes, perceptions, and philosophies of extension agents could be used as a foundation for extension workers to transfer SAP to the farmers. However, to our knowledge, no studies conducted in Malaysia have examined the relationship between extension workers' attitude, perception, philosophy, and knowledge regarding SAP and the transfer of SAP. Moreover, there is no investigation on the contribution of these variables in the process of transferring SAP. Boone, Hersman, Boone, and Gartin (2007) recommended that future research study if knowledge and attitudes toward SAP influence the transfer of information to farmers. It is not clearly known what role extension workers' philosophy, attitude, knowledge, and perception of SAP play in the transfer of the program to farmers. Hence, in the present study, we aim to investigate the relationship between the variables and the importance of such variables in the transfer of SAP. This may help to uncover barriers prohibiting the transfer of SAP.

Objectives of the study:

1) Determine the relationship between extension workers 'philosophy, attitude, perception, knowledge, and transfer of SAP to farmers.

2) Assess the proposed four-factor regression model to explain the variation of transfer of SAP to farmers.

\section{Method}

This study was conducted in west Malaysia. Data for this survey was collected from front line agricultural extension workers, who work at the DOA and deal directly with farmers. A descriptive research design was used to collect data from extension workers. Data was collected using questionnaires administrated by competent field researcher. Pearson correlation was used to analyze the relationships between the independent and dependent variables of the study. Enter method regression was employed to determine to what extent variables selected for this study explain the variation of transferring SAP to the farmers.

\subsection{Participants}

The target population of this study consists of all front line agriculture extension workers in the DOA who deals directly with farmers. The sample consisted of 400 respondents. Respondents were selected randomly from the DOA in west Malaysia. 


\subsection{Sampling Procedures}

A list of the names of 690 agriculture extension workers was provided by the DOA. We determined that a sample size of 248 was needed to represent the population at a confidence level of ninety-five percent (Krejcie \& Morgan, 1970). However, the larger the sample size, the lesser the sampling error. Therefore, the required total sample size for the study was specified as 400 .

\subsection{Research Instrument}

Our instrument was adopted from previous studies conducted by Conners, Swan, and Brousseau (2004); Muma, Martin, Shelley, and Holmes (2010); and Chen (2003) with some modification. The questionnaire consisted of several sections. The first part, was designed to measure extension workers' philosophy on SAP. We included fourteen items in this section. The second part of the instrument was designed to measure extension workers' perception of SAP. Fifteen items were considered in order to measure this construct. The third section of the questionnaire measured the knowledge of extension workers with regard to SAP. We selected seven statements for this part. Extension workers' attitudes about SAP were measured using nineteen items investigating four dimensions of SAP, namely production efficiency, economic viability, environmental sustainability, and social responsibility. The dependent variable for this study is the extent to which extension workers transfer SAP to the farmers. We included eighteen items in this section. The content and validity of the questionnaire was checked by panel of university experts. Questionnaire reliability was thus assessed according to Chronbach's alpha. Respondents rated items using a semantic differential scale from 1 (strongly disagree) to 10 (strongly agree) for independent variables and from 1 (very low extent) to 10 (very high extent) for the dependent variable. The statistical analyses were conducted using IBM ${ }^{\circledR}$ SPSS ${ }^{\circledR}$ Statistics 20.

\section{Results}

The Pearson correlation coefficient was used to assess the relationship between the variables in this study. We applied MLR to asses the proposed four-factor regression model explaining the variation of transferring SAP to farmers. The statistical analyses were conducted using IBM ${ }^{\circledR}$ SPSS $®$ Statistics 20.

The results of the Pearson correlation coefficient show that the transfer of SAP to farmers is positively related to extension workers' philosophy regarding $\mathrm{SAP}(\mathrm{r}=0.630, p=0.001)$, extension workers' perception of $\mathrm{SAP}(\mathrm{r}=0.670$, $\left.p_{=} 0.001\right)$, extension workers' knowledge of SAP $\left(\mathrm{r}_{=} 0.688, p_{=} 0.001\right)$ and extension workers' overall attitude of $\operatorname{SAP}\left(\mathrm{r}_{\mathrm{r}} 0.651, p=0.001\right)$. (See table 1$)$

Table 1. Pearson correlations coefficient of independent and dependent variables

\begin{tabular}{lccccc}
\hline Variable & $\mathrm{Y}$ & $\mathrm{X} 1$ & $\mathrm{X} 2$ & $\mathrm{X} 3$ & $\mathrm{X} 4$ \\
\hline Transfer of SAP(Y) & 1.000 & & & & \\
Philosophy (beliefs and value)(X1) & $0.630^{*}$ & 1.000 & & & \\
Perception(X2) & $0.670^{*}$ & 0.664 & 1.000 & & \\
Knowledge(X3) & $0.688^{*}$ & 0.562 & 0.541 & 1.000 & \\
Overall Attitude(X4) & $0.651^{*}$ & 0.633 & 0.598 & 0.961 & 1.000 \\
\hline
\end{tabular}

*Significant at the level of 0.05

The MLR performed to determine the importance of variables in explaining dependent variable. (See table 2)

A four-factor linear regression model was proposed to explain the variation of transfer of SAP to farmers.

The equation proposed by the MLR is as follows:

$\mathrm{Y}=-.063+.179(\mathrm{X} 1)+.342(\mathrm{X} 2)+.297(\mathrm{X} 3)+.156(\mathrm{X} 4)+\mathrm{e}$

$\mathrm{Y}=$ Transfer of SAP

$\mathrm{b}_{0}=$ Constant

$\mathrm{X} 1=$ Philosophy (beliefs and value)

$\mathrm{X} 2=$ Perception

$\mathrm{X} 3=$ Knowledge 
$\mathrm{X} 4=$ Attitude

$\mathrm{e}=$ Error

Based on the method used, all variables found to be significant in explaining transfer of SAP to farmers. The predictor variable is philosophy (beliefs and value) $(\mathrm{t}=3.227, \mathrm{p}=0.000)$; perception $(\mathrm{t}=6.894, \mathrm{p}=0.000)$; knowledge $(\mathrm{t}=7.848, \mathrm{p}=0.000)$; and overall attitude $(\mathrm{t}=2.889, \mathrm{p}=0.000)$. As depicted in table 2, the largest beta coefficient is .347, which is for knowledge. The beta values for extension workers' perception of SAP (.302) is the second highest, followed by philosophy (.146) and attitude (.138). (See table 2)

The $\mathrm{R}^{2}$ value of 0.623 implies that four predictors explain $62.3 \%$ of the variances in the transfer of SAP to farmers. In other words, $62.3 \%$ of the variation in this transfer is accounted for by the variables in the model. (See table 2)

Table 2. Estimates of coefficients for the regression model

\begin{tabular}{|c|c|c|c|c|c|c|c|}
\hline \multirow{2}{*}{ Model } & \multicolumn{2}{|c|}{ Unstandardized Coefficients } & \multirow{2}{*}{$\begin{array}{c}\text { Standardized Coefficients } \\
\text { Beta }\end{array}$} & \multirow{2}{*}{$\mathrm{T}$} & \multirow{2}{*}{ Sig. } & \multicolumn{2}{|c|}{ Collinearity Statistics } \\
\hline & B & Std. Error & & & & Tolerance & VIF \\
\hline (Constant) & -.063 & .351 & & -.181 & .857 & & \\
\hline Philosophy & .179 & .055 & .146 & 3.227 & .001 & .463 & 2.160 \\
\hline Perception & .342 & .050 & .302 & 6.894 & .000 & .497 & 2.013 \\
\hline Knowledge & .297 & .038 & .347 & 7.848 & .000 & .487 & 2.051 \\
\hline Attitude & .156 & .054 & .138 & 2.889 & .004 & .417 & 2.396 \\
\hline
\end{tabular}

$\mathrm{R}=0.789 ; \mathrm{R}^{2}=0.623 ;$ Adjusted $\mathrm{R}^{2}=0.619$

\section{Discussion}

This paper has examined the relationship between attitude, perception, philosophy, knowledge, and the transfer of SAP in a sample of 400 Malaysian extension workers from the DOA. Results in the present paper support the importance of attitude, perception, philosophy, and knowledge among agricultural extension workers in the transfer of SAP to farmers. Based on the correlation results, attitude, perception, philosophy, and knowledge were found to be correlated to the transfer of SAP. The positive relationship suggests that the transfer of SAP is more apt to increase when extension workers' attitude, perception, philosophy, and knowledge on SAP increases. In other words, the transfer of SAP is expected to increase if extension workers obtain knowledge on SAP and acquire positive attitudes, perceptions, and philosophies on SAP. In addition, according to Cohen's criteria (1988, pp. 79-81), a correlation coefficient value above 0.50 indicates a strong relationship between variables. Comparing the correlation coefficient value obtained according to Cohen's criteria, the strongest linear relationship was found between extension workers' knowledge of SAP and the transfer of SAP $\left(\mathrm{r}_{2} 0.688, p_{=} 0.000\right)$. The second highest was found between extension workers' perception of SAP and the transfer of SAP $\left(\mathrm{r}_{\mathrm{n}}=0.670\right.$, $p=0.001)$. The next highest was between extension workers' attitudes on SAP and the transfer of SAP $\left(\mathrm{r}_{=} 0.651\right.$, $p=0.001)$. Finally, the lowest relationship was between extension workers' philosophy on SAP and the transfer of $\mathrm{SAP}\left(\mathrm{r}_{2} 0.630, p_{=} 0.001\right)$. The correlation results provide evidence to support a four-variable model for extension workers.

Results of regression indicate that extension workers' attitude, perception, knowledge, and philosophy significantly contribute in the transfer of SAP to farmers. Based upon the results, the largest beta coefficient is .347 for extension workers' knowledge, indicating that this variable makes the strongest contribution to explaining variance in the transfer of SAP when other variables in the model are controlled. This means that one standard deviation increase in extension workers' knowledge on SAP leads to a .347 increase of standard deviation in the transfer of SAP to farmers. Earlier studies also have reported the importance of SAP knowledge for extension workers (Agunga, 1995; Worstell, 1994; Minarovic \& Mueller, 2000; Al-Subaiee, Yoder \& Thompson, 2005; Karbasioun, Biemans \& Mulder, 2007; Chizari, Lindner \& Lashkarara, 2001).

The beta value for perception was the next highest (.302) followed by philosophy (.146) while the standardized coefficients for attitude was the smallest (.138), indicating that it made the least contribution. These results are in accordance with previous studies, which established similar findings that extension workers need to agree with SAP concepts to transfer information to farmers (Agunga, 1995; Udoto \& Flowers, 2001). A previous study also 
has reported that positive attitudes regarding SAP may influence extension workers to transfer SAP to farmers (Udoto \& Flower, 2001).

In Malaysia, government agencies are the most important sector to advance sustainable agriculture programs. Therefore, variables investigated in the current study must take into consideration by DOA to increase the transfer of SAP to farmers to increase the rate at which farmers adopt SAP. The DOA must make sure that extension workers' knowledge of SAP remains current. We recommend that the DOA undertake advanced training programs on SAP to enhance extension workers' SAP knowledge. Likewise, the responsibility of extension workers is to promote SAP and to facilitate the adoption of the program among Malaysian farmers. Hence, it is vital for them to acquire positive attitudes and perceptions on the value of SAP in order to convince farmers' adoption.

Since extension workers continue to participate in SAP activities, a clear understanding of SAP is crucial for them. This study suggests that more research should be conducted among agricultural extension workers in different agricultural agencies in Malaysia to understand their philosophy, attitude, perception, and knowledge regarding SAP.

\section{Acknowledgements}

We would like to thank the Research Management Center (RMC) in UPM, which supported this study.

\section{References}

Agunga, R. A. (1995). What Ohio extension agents say about sustainable agriculture. Journal of Sustainable Agriculture, 5(3), 169-187. http://dx.doi.org/10.1300/J064v05n03_13

Allahyari, M. S. (2009). Agricultural sustainability: Implications for extension systems. African Journal of Agricultural Research, 4(9), 781-786.

Allahyari, M. S., Branch, R., \& Rasht, I. (2008). Extensionists' attitude toward sustainable agriculture in Iran. Journal of Applied Sciences, 8(20), 3761-3763. http://dx.doi.org/10.3923/jas.2008.3761.3763

Alonge, A. J., \& Martin, R. A. (1995). Assessment of the adoption of sustainable agriculture practices: Implications for agricultural education. Journal of Agricultural Education, 36(3), 34-42. http://dx.doi.org/10.5032/jae.1995.03034

Al-Subaiee, S. S., Yoder, E. P., \& Thomson, J. S. (2005). Extension agents' perceptions of sustainable agriculture in the Riyadh Region of Saudi Arabia. Journal of International Agricultural and Extension Education, 12(1), 5-14. http://dx.doi.org/10.5191/jiaee.2005.12101

Barrow, C. J., Ngai Weng, C., \& Masron, T. (2009). Issues and challenges of sustainable agriculture in the Cameron Highlands. Malaysian Journal of Environmental Management, 10(2), 89-114.

Boone, H., Hersman, E. M., Boone, D. A., \& Gartin, A. A. (2007). Knowledge of sustainable agriculture practices by extension agents in Ohio, Pennsylvania and West Virginia. Journal of Extension. Retrieved from http://www.joe.org/joe/2007october/rb2.shtml

Chen, H. Y. (2003). Assessing faculty perceptions of the ecological paradigm of the college of food. Agricultural and Environmental Sciences (Doctoral dissertation, Ohio State University).

Chizari, M., Lindner, J. R., \& Lashkarara, F. (2001). Perceptions of Lurestan Province, Iran wheat farmers with respect to sustainable agricultural practices. Journal of International Agricultural and Extension Education, 8(3), 65-72. http://dx.doi.org/10.5191/jiaee.2001.08308

Chizari, M., Lindner, J. R., \& Zoghie, M. (1999). Perceptions of Extension Agents' Educational Needs Regarding Sustainable Agriculture in the Khorasan Province, Iran. Journal of Agricultural Education, 40, 20-27. http://dx.doi.org/10.5032/jae.1999.04020

Cho, K. M., \& Boland, H. (2004). Education and extension for multi-functional agriculture: Extension concepts for sustainable agricultural development in Myanmar. Proceedings of 20th Annual Conference of the Association for International Agricultural Extension and Education (AIAEE), 23-29.

Christopher, T. B. S. (2012). Organic agriculture and food in Malaysia. Christopher Teh Boon Sung. Retrieved June 26, 2013, from http://christopherteh.com/blog/2012/02/organic-agriculture/

Cohen, J. (1988). Statistical power analysis for the behavioural sciences (2nd ed.). Hillsdale, NJ: Erlbaum. 
Connors, J. J., Swan, B., \& Brousseau, J. A. (2004, May). Lithuanian agriculture teachers' perceptions on agricultural production, economics, environment, and social responsibility issues. Proceedings of the 20th Annual Conference of the AIAEE, 25-33.

Horrigan, L., Lawrence, R. S., \& Walker, P. (2002). How sustainable agriculture can address the environmental and human health harms of industrial agriculture. Environmental health perspectives, 110(5), 445. http://dx.doi.org/10.1289/ehp.02110445

Karbasioun, M., Biemans, H., \& Mulder, M. (2007). Supporting role of the agricultural extension services and implications for agricultural extension instructors as perceived by farmers in Esfahan, Iran. Journal of International Agricultural and Extension Education, 14(1), 31-44. http://dx.doi.org/10.5191/jiaee.2007.14103

Krejcie, R. V., \& Morgan, D. W. (1970). Determining sample size for research activities. Educational Psychology Measures.

Liaghati, H., Veisi, H., Hematyar, H., \& Ahmadzadeh, F. (2008). Assessing the student's attitudes towards sustainable agriculture. American. Eurasian Journal of Agricultural Environmental. Science, 3, 227-232.

Minarovic, R. E., \& Mueller, J. P. (2000). North Carolina cooperative extension service professionals' attitudes toward sustainable agriculture. Journal of extension, 38(1), 2-11. Retrieved from http://www.joe.org/joe/2000february/a1.php

Muma, M., Martin, R., Shelley, M., \& Holmes Jr., L. (2010). Sustainable agriculture: Teacher beliefs and topics taught. Journal of Sustainable Agriculture, 34(4), 439-459. http://dx.doi.org/10.1080/10440041003680312

Pretty, J. N. (1995). Regenerating agriculture: policies and practice for sustainability and self-reliance. NY: Joseph Henry Press.

Röling, N., \& Van de Fliert, E. (1994). Transforming extension for sustainable agriculture: the case of integrated pest management in rice in Indonesia. Agriculture and Human Values, 11(2-3), 96-108. http://dx.doi.org/10.1007/BF01530451

Straquadine, G. S. (1997). An assessment of agricultural education teachers' agriculture understanding and instructional materials use. Proceedings of the Southern and Western Regions Agricultural Education Research Meeting, 252-261.

Tiraieyari, N., \& Uli, J. (2011). Sustainable Agriculture in Malaysia: Implication for Extension Workers. Journal of American Science, 7(8). 179-182. Retrieved from http://www.americanscience.org

Tiraieyari, N., Hamzah, A., Samah, B. A., \& Uli, J. (2013a). Attitudes of Malaysian extension workers towards sustainable agricultural practices. American Journal of Environmental Scince, 9, 33-37. http://dx.doi.org/10.3844/ajessp.2013.33.37

Tiraieyari, N., Hamzah, A., Samah, B. A., \& Uli, J. (2013b). Knowledge and perceptions of extension workers on sustainable agricultural practices. American Journal of Environmental Scince, 9, 45-50. http://dx.doi.org/10.3844/ajessp.2013.45.50

Udoto, M., \& Flowers, J. (2001). Perceptions of agricultural education teachers toward sustainable agricultural practices. Proceedings of the $28^{\text {th }}$ Annual National Agricultural Education Research Conferences, 443-444.

Williams, D. L. (2000). Students' knowledge of and expected impact from sustainable agriculture. Journal of Agricultural Education, 41, 19-24. http://dx.doi.org/10.5032/jae.2000.02019

Williams, D. L., \& Wise, K. L. (1997). Perceptions of Iowa secondary school agricultural education teachers and students regarding sustainable agriculture. Journal of Agricultural Education, 38(2), 15-20. http://dx.doi.org/10.5032/jae.1997.02015

Worstell, J. V. (1995). Paths to sustainable rural development: Conclusions from the "state of the South" project. Local Communities and Sustainable Development: Proceedings of the 52nd Annual Professional Agricultural Workers Conference, 52, 15.

\section{Copyrights}

Copyright for this article is retained by the author(s), with first publication rights granted to the journal.

This is an open-access article distributed under the terms and conditions of the Creative Commons Attribution license (http://creativecommons.org/licenses/by/3.0/). 